\title{
健常者によるThymoxamine hydrochlorideの
}

\section{経静脈単一投与試験}

—— 持続収縮期血圧計および深部温度計の応用 —

\author{
中島光 好* 鈴木国 文* 橋 本 久 邦* \\ （受付：1979 年 2 月 1 日）
}

Intravenous Single-Injection Study of Thymoxamine Hydrochloride in Healthy Volunteers

\section{Mitsuyoshi NAKASHIMA* Kunifumi SUZUKI* and Hisakuni HASHIMOTO*}

* Department of Pharmacology, Hamamatsu University School of Medicine

The pharmacokinetics, pharmacodynamics and safety of thymoxamine were studied in 3 healthy male subjects by intravenous injection of thymoxamine hydrochloride at doses of 2,5 and $10 \mathrm{mg}$. Each subject recieved one dose at each level, the amount increasing with each week's injection.

Each subject rested in supine position on the examination bed while the following parameters were continuously monitored for 2-3 hours : systolic blood pressure ; deep body temperature at the forehead, palm and sole; fingertip skin temperature; blood flow in the skin at the wrist ; ECG; and respiratory rate.

Thymoxamine tended to lower the blood pressure and elevate the peripheral temperature. Some subjects had a warm feeling at the extremities and flushed feeling at the cheeks.

The ECG and the respiratory rate showed no significant change. The half time of this drug was found to be $83 \mathrm{~min}$. The urinary excretion rate was $20.3 \%$ within 24 hours. The feces excretion rate was $2.0 \%$ within 72 hours. No side effect noted in laboratory tests were observed during this study.

Key Words : Thymoxamine hydrochloride, Continuous systolic blood pressure, Deep body temperature, Healthy volunteers 


\section{はじめに}

Thymoxamine hydrochloride は, すでに欧州 各国で高血圧, 脳循環不全, 気管支喘息, 緑内障 の治療にひろく使用されている薬剤である.

さきに，われわれ， thymoxamine hydrochloride の日本人健常者に対する単一経口投与試 験 ${ }^{1)}$ と 5 日間の連続経口投与試験 ${ }^{2}$ を行い, その安 全性と薬物動態について報告した。この薬剂は易 水溶性であり, 脳循環不全, 末梢循環不全などに 注射でも用いられ得る。そこで, 注射時の安全性, 薬物動態を検討すると共に, 薬力学的作用を明ら かにするため, 収縮期血圧, 深部温, 末梢皮膚温, 末梢皮膚血流，心電図，呼吸数などを連続記録し， 種々の知見を得たのでここに報告する.

本試験は, 昭和 53 年 1 月より 53 年 2 月までの 期間, 浜松医科大学の関連病院である県西部浜松 医療センターにて行った.

\section{対象および方法}

\section{1. 被験者の選択}

健康な男子志願者に前回 ${ }^{122)}$ 之同様の検査を行 い異常を認めなかった者より，本剤の性質・薬理 作用・副作用，本試験の目的・方法・期間などを 説明し，書面での同意を得た 3 名を被験者とした (Table 1).

\section{2. 試験スケジュール}

各用量群とも Table 2 に示したスケジュール に従って行った. 試験前日の夜より入院させ, 翌 朝問診, 聴打診, ECG に異常のないことを確認し てから, 臨床検査用採血を行って後, 本剂を注射 した. 投与量の増加は，入院中の検査データおよ び投薬後 $24 \mathrm{hr}$ と 5 日目に実施した臨床検査成績
などか.ら異常のないことを確認して決定した. 同 一被験者にて, $2 \mathrm{mg}, 10 \mathrm{mg}$ と増加させた. 投与間 隔は7日とした。

\section{3 . 投与方法}

Thymoxamine hydrochloride のそれぞれ 2 $\mathrm{mg}, 5 \mathrm{mg}, 10 \mathrm{mg}$, を $20 \mathrm{ml}$ の生理食塩液に溶解し 5 min かけて静注した。用量は外国での臨床用 量 ${ }^{3)}$ を参考にして決定した。推定臨床用量は $5 \mathrm{mg}$, 推定耐薬量は $10 \mathrm{mg}$ と設定した.

\section{4. 自覚症状}

前回 ${ }^{1) 2}$ 用いたと同じ円形調査表に被験者自身 が記録するようにした。

\section{5 検査項目}

1) 薬力学的検索

上腕血圧, 口腔内体温, 脈拍を注射終了後 5 , $10,20,40,60,120,180 \mathrm{~min}$ に測定した. 同時 に, ECG, 呼吸数, 収縮期血圧, 脈拍数, 前額 - 手 掌・足蹠の深部温, 指尖腹部の皮膚温および手首 の皮膚血流量を投与後 $1 \mathrm{hr}$ まで連続記録した. 収 縮期血圧损よび脈拍数は自動連続収縮期血圧記録 器(島津製 SCS-501) を用いて指尖にて測定した。 深部温，皮䖒温は, Finer Core Temp（テルモ製 DC-1）を用い, 皮膚血流は, 交差熱電対（ユニクメディカル製 UM-2000）を使用した。 さらに, $10 \mathrm{mg}$ 投与時には, 呼吸抵抗計 (日本光電 MZR4000）を用いて注射後 $1 \mathrm{hr}$ での呼吸抵抗を測定 し, 注射前值と比較した. また投与後 $80 \mathrm{~min}$ の血 小板凝集能も測定し，投与前と比較した.

2 ）尿・血液および血液生化学検査

投与直前损よび投与後 $24 \mathrm{hr}$ に測定した. さら に5 日後にも一部の検査を試行し, 安全性を再確 認した。

Table 1 Ages, Body Weights and Blood Pressures of Subjects

\begin{tabular}{|c|c|c|c|c|c|c|}
\hline \multirow{2}{*}{$\begin{array}{l}\text { Case No. } \\
\text { (Subject) }\end{array}$} & \multirow{2}{*}{ Age } & \multirow{2}{*}{$\begin{array}{c}\text { Body weight } \\
(\mathrm{kg})\end{array}$} & \multirow{2}{*}{$\begin{array}{l}\text { Blood pressure } \\
\qquad(\mathrm{mmHg})\end{array}$} & \multicolumn{3}{|c|}{ Dose, i. v., single } \\
\hline & & & & $2 \mathrm{mg}$ & $5 \mathrm{mg}$ & $10 \mathrm{mg}$ \\
\hline 1. Y.T. & 30 & 60 & $102 / 50$ & 0 & 0 & 0 \\
\hline 2. U.S. & 27 & 48 & $128 / 82$ & 0 & 0 & $\bigcirc$ \\
\hline 3. T. M. & 24 & 60 & $126 / 78$ & $\bigcirc$ & $\bigcirc$ & $\bigcirc$ \\
\hline
\end{tabular}


Table 2 Schedule of Single Intravenous Administration Study $2 \mathrm{mg}, 5 \mathrm{mg}, 10 \mathrm{mg}$, i. v., single

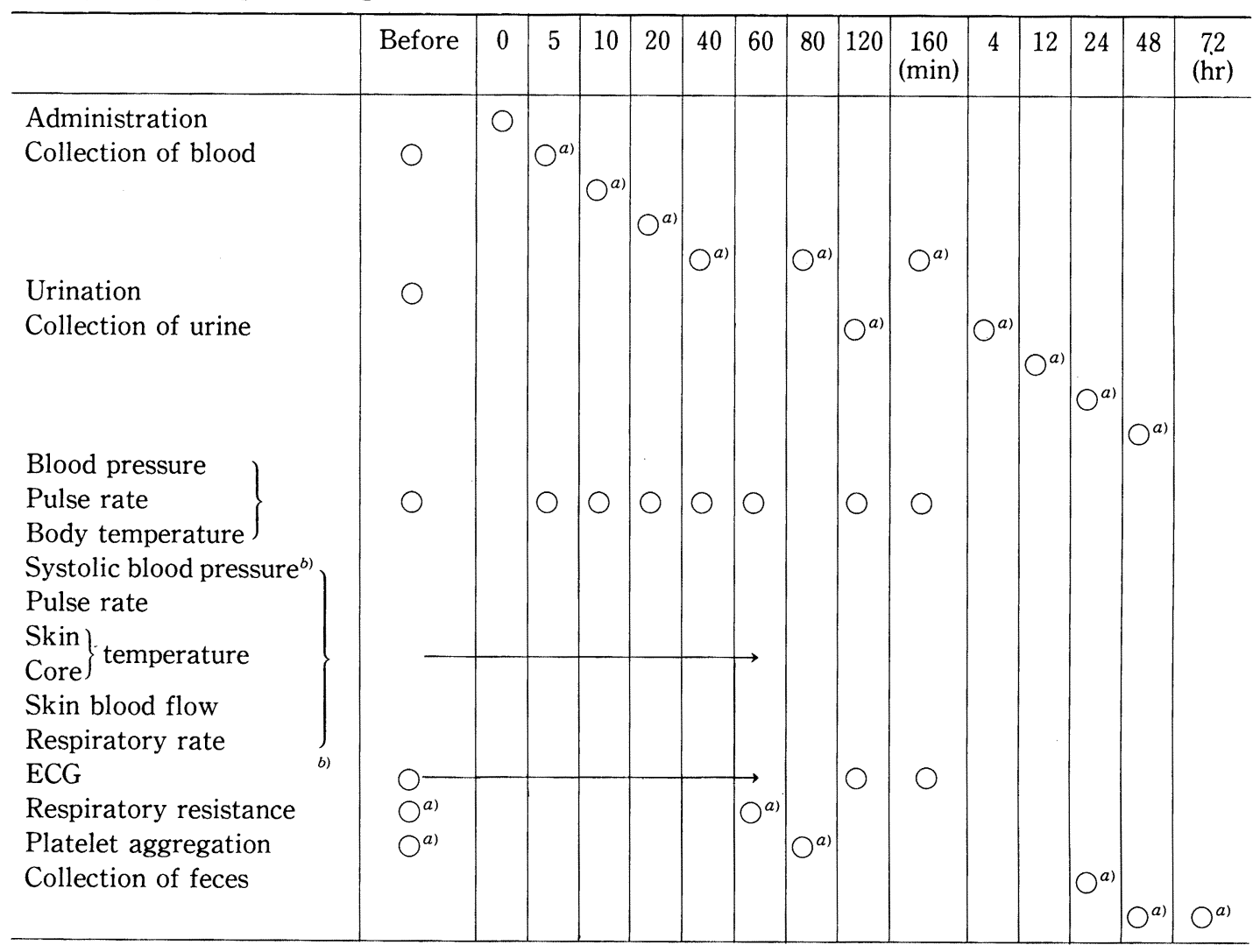

a) : $10 \mathrm{mg}$ thymoxamine i. v. administered group only

b) : continuous recording

\section{6. 薬物動態の検索}

$10 \mathrm{mg}$ 投与時, 血中濃度測定のために, 注射前, 注射終了後 $5,10,20,40,80,160$ min の計 7 回 採血を行った. 尿は, Table 2 に示したスケジュー ルで $48 \mathrm{hr}$ 後まで採取し, 便は, 3 日後まで採集し 分析に供した。定量は富士臓器製薬株式会社研究 所にて行った．測定対象とされたのは deacetylthymoxamine (DAM) と demethylthymoxamine (Met-X) である1). 未変化の thymoxamine は血 中ですみやかに分解され，上記代謝物となるため 測定不能であった.

\section{試験結果}

\section{1. 自覚症状}

延 9 名中 5 名に手足が暖かくなるといら訴えが
あった. $10 \mathrm{mg}$ 投与時 2 名は軽度顔面紅潮を訴え た. 1 名は投与 $20 \mathrm{~min}$ 後の採血直後に腹部熱感, 蠕動, 冷汗を訴えたが 2 3 min でほぼ回復した。

\section{2. 薬力学的変化}

1) ECG : 各用量とも変化は認められなかっ た.

2 ）間歇的に測定された上腕血圧・脈拍数・体 温の変化: $2 \mathrm{mg}, 5 \mathrm{mg}, 10 \mathrm{mg}$ 各投与量での測定 值を Table 3 に示す．また，各投与群での 3 名の 平均値をグラフに示す (Fig. 1,2,3). $2 \mathrm{mg}$ 群では, 注射後 $1 \mathrm{hr}$ まで収縮期血圧, 拡張期血圧ともやや 低下したが, 同一被験者でも $5 \mathrm{mg}$ では, 拡張期の みに低下傾向を示した，体温，脈拍数には著変は なかった. $10 \mathrm{mg}$ 投与群では，全般的に収縮期血 圧, 拡張期圧の低下と脈拍数の増加が認められた。 
Table 3a Influence of Intravenous Single Administration of Thymoxamine on Blood Pressure, Pulse Rate and Body Temperature

\begin{tabular}{|c|c|c|c|c|c|c|c|c|c|c|}
\hline \multirow{2}{*}{ Dose } & \multirow{2}{*}{$\begin{array}{l}\text { Case No. } \\
\text { (Subject) }\end{array}$} & \multirow{2}{*}{ Items } & \multirow{2}{*}{ Before } & \multicolumn{7}{|c|}{ Minutes after administration } \\
\hline & & & & 5 & 10 & 20 & 40 & 60 & 120 & 180 \\
\hline \multirow{13}{*}{$\begin{array}{l}2 \mathrm{mg}, \\
\text { i. v., } \\
\text { single }\end{array}$} & \multirow[t]{3}{*}{ 1. (Y.T.) } & B. P. & $126 / 64$ & $127 / 64$ & $128 / 58$ & $118 / 54$ & $126 / 70$ & $120 / 70$ & $118 / 60$ & $120 / 58$ \\
\hline & & P. R. & 72 & 73 & 70 & 67 & 71 & 74 & 66 & 66 \\
\hline & & B. Temp. & 36.6 & 36.5 & 36.5 & 36.5 & 36.4 & 36.4 & 36.5 & 36.6 \\
\hline & \multirow[t]{3}{*}{ 2, (U.S.) } & B. P. & $120 / 70$ & $100 / 56$ & $100 / 58$ & $104 / 58$ & $110 / 38$ & $108 / 60$ & $106 / 50$ & $105 / 54$ \\
\hline & & P.R. & 77 & 80 & 76 & 80 & 75 & 74 & 76 & 77 \\
\hline & & B. Temp. & 36.6 & 36.5 & 36.6 & 36.8 & 36.8 & 36.6 & 36.6 & 36.6 \\
\hline & \multirow[t]{3}{*}{ 3. (T.M.) } & B. P. & $111 / 63$ & $108 / 62$ & $108 / 58$ & $102 / 56$ & $100 / 52$ & $100 / 65$ & $116 / 60$ & $110 / 50$ \\
\hline & & P. R. & 53 & 62 & 55 & 49 & 53 & 55 & 63 & 57 \\
\hline & & B. Temp. & 36.3 & 36.2 & 36.3 & 36.1 & 36.1 & 36.2 & 36.3 & 36.1 \\
\hline & \multirow{4}{*}{ Mean \pm S.D. } & \multirow{2}{*}{ B. P. } & $119 \pm 7.5$ & $112 \pm 13.9$ & $112 \pm 14.4$ & $108 \pm 8.7$ & $112 \pm 13.1$ & $109 \pm 10.1$ & $113 \pm 6.4$ & $112 \pm 7.6$ \\
\hline & & & $66 \pm 3.8$ & $61 \pm 4.2$ & $58 \pm 0.0$ & $56 \pm 2.0$ & $53 \pm 16.7$ & $65 \pm 5.0$ & $57 \pm 5.8$ & $54 \pm 4.0$ \\
\hline & & P. R. & $67 \pm 13$ & $72 \pm 9$ & $67 \pm 11$ & $65 \pm 16$ & $66 \pm 12$ & $68 \pm 11$ & $68 \pm 7$ & $67 \pm 10$ \\
\hline & & B. Temp. & $36.5 \pm 0.2$ & $36.4 \pm 0.2$ & $36.5 \pm 0.2$ & $36.5 \pm 0.4$ & $36.4 \pm 0.4$ & $36.4 \pm 0.2$ & $36.5 \pm 0.2$ & $36.4 \pm 0.3$ \\
\hline
\end{tabular}

Table 3b Influence of Intravenous Single Administration of Thymoxamine on Blood Pressure, Pulse Rate and Body Temperature

\begin{tabular}{|c|c|c|c|c|c|c|c|c|c|c|}
\hline \multirow{2}{*}{ Dose } & \multirow{2}{*}{$\begin{array}{l}\text { Case No. } \\
\text { (Subject) }\end{array}$} & \multirow{2}{*}{ Items } & \multirow{2}{*}{ Before } & \multicolumn{7}{|c|}{ Minutes after administration } \\
\hline & & & & 5 & 10 & 20 & 40 & 60 & 120 & 180 \\
\hline \multirow{12}{*}{$\begin{array}{l}5 \mathrm{mg}, \\
\text { i.v., } \\
\text { single }\end{array}$} & \multirow[t]{3}{*}{ 1. (Y.T.) } & B. P. & $110 / 62$ & $108 / 60$ & $108 / 62$ & $120 / 60$ & $116 / 62$ & $112 / 62$ & $100 / 36$ & $106 / 78$ \\
\hline & & P. R. & 64 & 61 & 67 & 63 & 61 & 61 & 64 & 58 \\
\hline & & B. Temp. & 36.4 & 36.3 & 36.2 & 36.1 & 36.3 & 36.2 & 36.4 & 36.4 \\
\hline & \multirow[t]{3}{*}{ 2. (U.S.) } & B. P. & $102 / 50$ & $104 / 48$ & $110 / 42$ & $108 / 38$ & $110 / 44$ & $108 / 48$ & $114 / 60$ & $120 / 42$ \\
\hline & & P. R. & 65 & 69 & 70 & 73 & 67 & 67 & 66 & 77 \\
\hline & & B. Temp. & 36.5 & 36.4 & 36.4 & 36.4 & 36.4 & 36.4 & 36.0 & 36.3 \\
\hline & \multirow[t]{3}{*}{ 3. (T.M.) } & B. P. & $100 / 58$ & $98 / 50$ & $102 / 48$ & $100 / 50$ & $106 / 64$ & $104 / 50$ & $106 / 56$ & $116 / 48$ \\
\hline & & P. R. & 42 & 51 & 45 & 44 & 49 & 54 & 51 & 54 \\
\hline & & B. Temp. & 36.3 & 36.1 & 36.1 & 36.0 & 36.0 & 36.0 & 36.5 & 36.7 \\
\hline & \multirow[t]{3}{*}{ Mean \pm S.D. } & B. P. & $\frac{104 \pm 5.3}{57 \pm 6.1}$ & $\frac{103 \pm 5.0}{53 \pm 6.4}$ & $\frac{107 \pm 4.2}{51 \pm 10.3}$ & $\frac{109 \pm 10.1}{47 \pm 11.0}$ & $\frac{111 \pm 5.0}{57 \pm 11.0}$ & $\frac{108 \pm 4.0}{53 \pm 7.6}$ & $\frac{107 \pm 7.0}{51 \pm 12.9}$ & $\frac{114 \pm 7.2}{46 \pm 3.5}$ \\
\hline & & P. R. & $57 \pm 13$ & $60 \pm 9$ & $61 \pm 14$ & $60 \pm 15$ & $59 \pm 9$ & $61 \pm 7$ & $60 \pm 8$ & $63 \pm 13$ \\
\hline & & B. Temp. & $36.4 \pm 0.1$ & $36.3 \pm 0.2$ & $36.2 \pm 0.2$ & $36.2 \pm 0.2$ & $36.2 \pm 0.2$ & $36.3 \pm 0.2$ & $36.3 \pm 0.3$ & $36.5 \pm 0.2$ \\
\hline
\end{tabular}


Table 3c Influence of Intravenous Single Administration of Thymoxamine on Blood Pressure, Pulse Rate and Body Temperature

\begin{tabular}{|c|c|c|c|c|c|c|c|c|c|c|}
\hline \multirow{2}{*}{ Dose } & \multirow{2}{*}{$\begin{array}{l}\text { Case No. } \\
\text { (Subject) }\end{array}$} & \multirow{2}{*}{ Items } & \multirow{2}{*}{ Before } & \multicolumn{7}{|c|}{ Minutes after adminstration } \\
\hline & & & & 5 & 10 & 20 & 40 & 60 & 120 & 180 \\
\hline \multirow{13}{*}{$\begin{array}{l}10 \mathrm{mg}, \\
\text { i. v., } \\
\text { single }\end{array}$} & \multirow[t]{3}{*}{ 1. (Y.T.) } & B. P. & $102 / 50$ & $104 / 36$ & $80 / 34$ & $100 / 38$ & $104 / 36$ & $104 / 40$ & $107 / 41$ & $109 / 43$ \\
\hline & & P. R. & 64 & 70 & 74 & 80 & 74 & 75 & 71 & 73 \\
\hline & & B. Temp. & 35.3 & 35.2 & 35.3 & 35.7 & 35.4 & 35.4 & 35.6 & 35.6 \\
\hline & \multirow[t]{3}{*}{ 2. (U.S.) } & B. P. & $104 / 60$ & $102 / 50$ & $102 / 48$ & $100 / 44$ & $106 / 58$ & $108 / 60$ & $105 / 50$ & $102 / 40$ \\
\hline & & P. R. & 76 & 75 & 75 & 73 & 66 & 71 & 71 & 75 \\
\hline & & B. Temp. & 36.7 & 36.6 & 36.6 & 36.6 & 36.2 & 35.9 & 36.0 & 36.1 \\
\hline & \multirow[t]{3}{*}{ 3. (T.M.) } & B. P. & $110 / 58$ & $100 / 44$ & $98 / 40$ & $100 / 40$ & $106 / 50$ & $108 / 47$ & $114 / 40$ & $104 / 50$ \\
\hline & & P. R. & 50 & 60 & 62 & 57 & 51 & 52 & 57 & 56 \\
\hline & & B. Temp. & 36.6 & 36.3 & 36.2 & 36.2 & 36.3 & 36.3 & 36.5 & 36.6 \\
\hline & \multirow{4}{*}{ Mean \pm S.D. } & \multirow{2}{*}{ B. P. } & $105 \pm 4.2$ & $102 \pm 2.0$ & $93 \pm 11.7$ & $100 \pm 0.0$ & $105 \pm 1.2$ & $107 \pm 2.3$ & $109 \pm 4.7$ & $105 \pm 3.6$ \\
\hline & & & $56 \pm 5.3$ & $43 \pm 7.0$ & $\widehat{41 \pm 7.0}$ & $41 \pm 3.1$ & $\widehat{48} \pm 11.1$ & $\widehat{49} \pm 10.1$ & $44 \pm 5.5$ & $\widehat{44 \pm 5.1}$ \\
\hline & & P. R. & $63 \pm 13$ & $68 \pm 8$ & $70 \pm 7$ & $70 \pm 12$ & $64 \pm 12$ & $66 \pm 12$ & $66 \pm 8$ & $68 \pm 10$ \\
\hline & & B. Temp. & $36.2 \pm 0.8$ & $36.0 \pm 0.7$ & $36.0 \pm 0.7$ & $36.2 \pm 0.5$ & $36.0 \pm 0.5$ & $35.9 \pm 0.5$ & $36.0 \pm 0.5$ & $36.1 \pm 0.5$ \\
\hline
\end{tabular}

被験者 No. 1 は, 投与前血圧が 102/50 であったの が, 投与 $10 \mathrm{~min}$ 後に血圧は 80/34 と低下した.こ の際自覚症状は伴わなかった。これはすみやかに 回復し, $20 \mathrm{~min}$ 後には 100/38 となったが, 採血直 後に腹部熱感, 蠕動, 冷汗を訴え, 血圧は再び低 下し, $22 \mathrm{~min}$ 後には $80 / 20$ となり脈拍数は 64 か ら 80 へと増加した. $24 \mathrm{~min}$ 後には自然に回復し, 血圧は $110 / 60$ となり脈拍数も前値に復した.

3 ）連続記録による ECG・収縮期血圧・脈拍 数・深部温-皮膚温・皮膚血流・呼吸数の变化: ECG において不整脈などの異常所見は全例に認 められなかった。

収縮期血纴は, $2 \mathrm{mg}, 5 \mathrm{mg}$ では著変はなかった が, $10 \mathrm{mg}$ ではやや低下した. Fig. 4 にその 1 例 を示す. 特に上記被験者 No.1 では, 投薬後 20 min の採血後に, 収縮期圧が著明に低下し, 回復は 徐々で約 $50 \mathrm{~min}$ を要した. 脈拍数は血圧低下に 伴い上昇したが, 2 3 min で低下しその後は投薬 前值よりやや低めに経過した (Fig. 5).

一般に, 注射後足蹠・手掌の深部温, 手指の皮 膚温は上昇傾向を示した. Fig. 4-B にその一例を

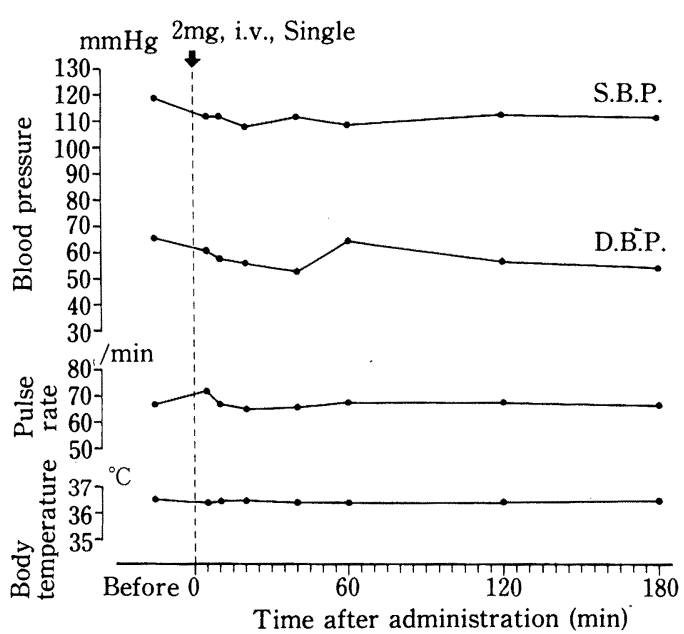

Fig. 1 Changes in blood pressure, pulse rate and body temperature of three subjects after intravenous administration of $2 \mathrm{mg}$ thymoxamine.

S. B. P. ; Systolic blood pressure

D. B. P. ; Diastolic blood pressure

示すが，手掌は，一過性の低下後上昇し，足蹠深 部温は，ただちに上昇している．前額深部温はほ とんど変化しない. $10 \mathrm{mg}$ 投与に拉ける著明な血 
圧低下の一例では, 血圧低下に伴い, 足蹠, 手掌, 手指温はそれぞれ約 $0.2,0.4,0.7^{\circ} \mathrm{C}$ 下降した. 前 額深部温も徐々に約 $0.3^{\circ} \mathrm{C}$ 低下した。回復時間は 約 $15 \mathrm{~min}$ ，前額部深部温は約 $50 \mathrm{~min}$ を要した (Fig. 6). 皮膚血流は一定の傾向を示さなかった が，急性血圧降下例では低下を示した．呼吸数に は著明な変化は認められなかった。

4) 呼吸抵抗：10 mg 投与時に扣いて測定した 呼吸抵抗は Table 4 に示した. 3 名とも上昇傾向

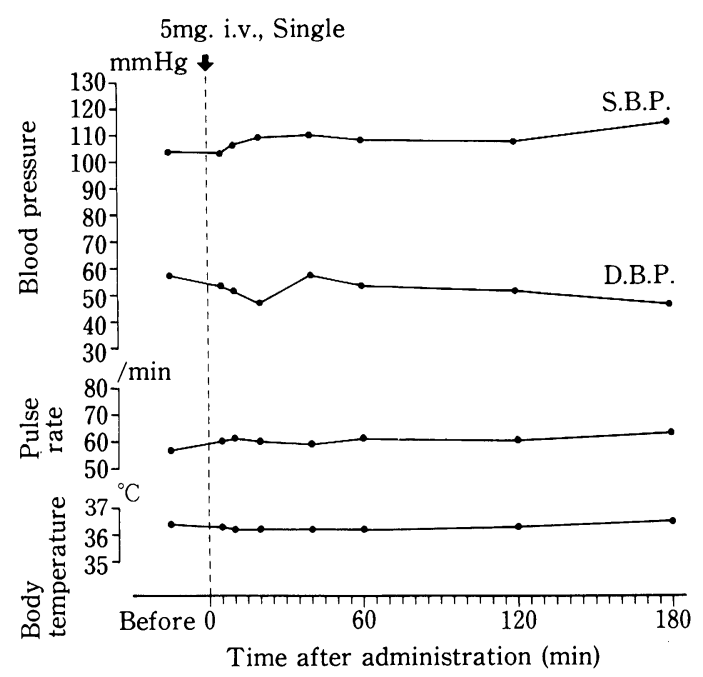

Fig. 2 Changes in blood pressure, pulse rate and body temperature of three subjects after intravenous administration of $5 \mathrm{mg}$ thymoxamine.

S. B. P. ; Systolic blood pressure

D. B. P. ; Diastolic blood pressure
を示している.

5 ）血小板凝集能：血小板凝集能は投与前後で 一定の変化は認められなかった (Table 5).

\section{3 . 臨床検査成績}

1) 血液学的検査：異常所見は認められなかっ た (Table 6).

2）血液生化学的検査: Table 6 にその結果を 示すが，異常值を示したものはなかった.

3 ）尿検査：被験者 No.2 (U.S.) は $2 \mathrm{mg}$ 投与

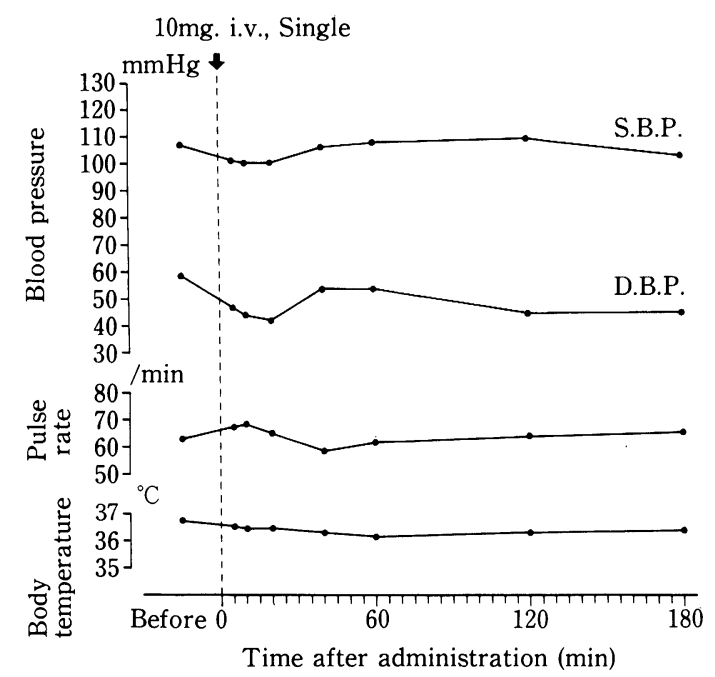

Fig. 3 Changes in blood pressure, puse rate and body temperature of three subjects after intravenous administration of $10 \mathrm{mg}$ thymoxamine.

S. B. P. ; Systolic blood pressure

D. B. P. ; Diastolic blood pressure

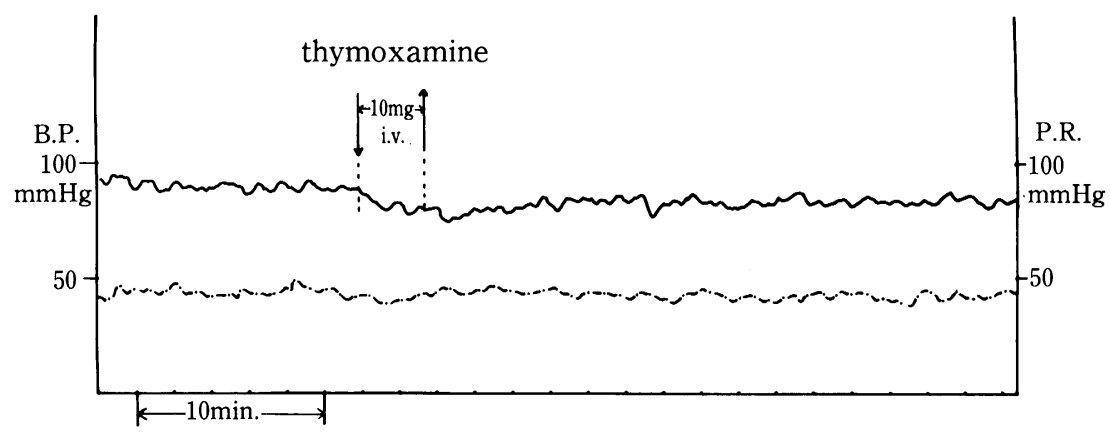

Fig. 4-A Influence of thymoxaine $10 \mathrm{mg}$ i. v. on systolic blood pressure and pulse rate. - Systolic blood pressure

-...-.-Pulse rate 
後 $24 \mathrm{hr}$ で尿蛋白陽性を示したが, 他の検査に何 ら異常所見はなく, $5 \mathrm{mg}, 10 \mathrm{mg}$ 投与時には尿蛋 白陰性であり, 他にも異常所見は認められなかっ た (Table 6).

\section{4. 薬物動態}

1) 血中濃度: $10 \mathrm{mg}$ 投与時の DAM と Met -X の血中濃度は Table 7 と Fig. 7 に示したが, その半減期は約 $83 \mathrm{~min}$ である.

2 ）尿中排泄: $24 \mathrm{hr}$ 以内に投与量の $20.3 \%$ 排泄される. 24-28 hr の排泄はごく少量であった

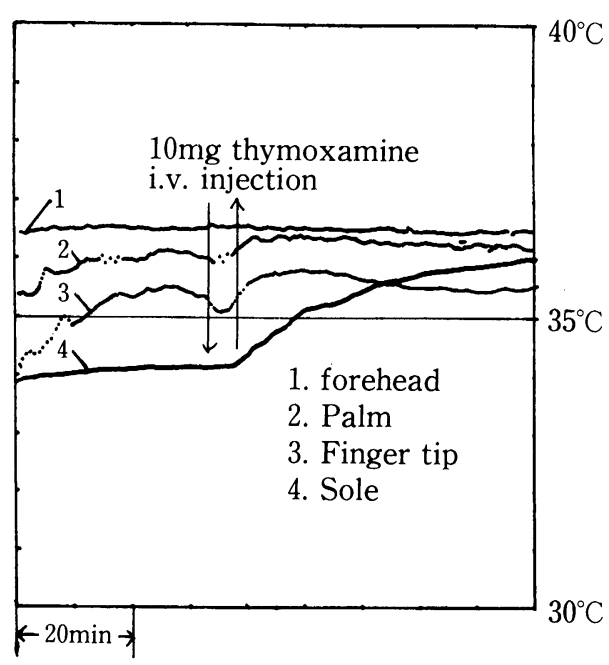

Fig. 4-B Influence of thymoxamine $10 \mathrm{mg}$ i. v. on body temperature.

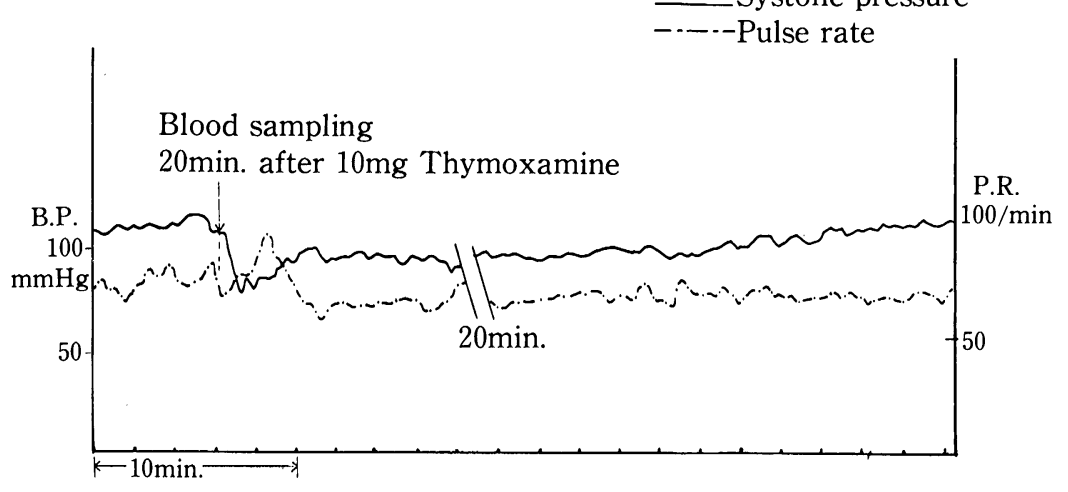

Fig. 5 "Acute hypotension" observed after intravenous administration of $10 \mathrm{mg}$ thymoxamine.
(Table 8, Fig.8).

3 ) 便中排泄：3日目まで便中にDAM と

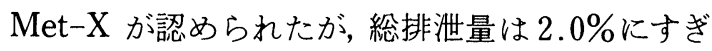
ない (Table 8).

本剂は $\alpha$ 受容体遮断剂であり ${ }^{4) ~ 6), ~}$ 静脈内投与 によって，末梢血管，血圧に影響をおよぼすこと が予想される. 外国での $10 \mathrm{mg}$ 静脈内投与の治験 例に拈いては, 下肢の有意の血流増大作用が報 告3されている.そこで, 本薬剤を静脈内に投与す るにあたって, 被験者の安全を確保し, 血行動態

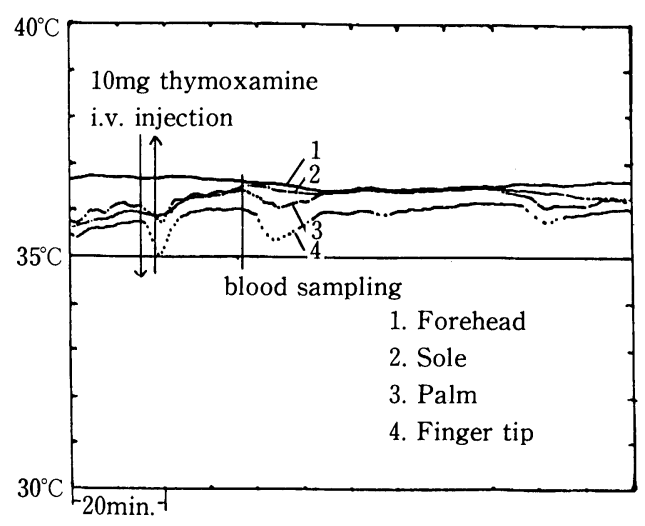

Fig. 6 Influence of intravenous administration of $10 \mathrm{mg}$ thymoxamine on body temperature.

Systolic pressure

- Systolic blood pressure

....-.Pulse rate 
Table 4 Influence of Thymoxamine on Respiratory Resistance

$10 \mathrm{mg}$, i. v., single

$\left(\mathrm{cmH}_{2} 0 / 1 / \mathrm{sec}\right)$

\begin{tabular}{ll|c|c}
\hline \multirow{2}{*}{$\begin{array}{c}\text { Case No. } \\
\text { (Subject) }\end{array}$} & \multirow{2}{*}{ Height } & \multicolumn{2}{|c}{$10 \mathrm{mg}$} \\
\cline { 3 - 4 } & & Before & After \\
\hline 1. (Y. T.) & $177 \mathrm{~cm}$ & 2.20 & 2.40 \\
2. (V.S.) & $162 \mathrm{~cm}$ & 2.20 & 2.90 \\
3. (T. M.) & $174 \mathrm{~cm}$ & 2.40 & 2.50 \\
\hline
\end{tabular}

Table 5 Influence of Thymoxamine on Platelets Aggregation

$10 \mathrm{mg}$, i. v., single

\begin{tabular}{c|c|c}
\hline $\begin{array}{c}\text { Case No. } \\
\text { (Subject) }\end{array}$ & $\begin{array}{c}\text { before } \\
(\%)\end{array}$ & $\begin{array}{c}\text { after } \\
(\%)\end{array}$ \\
\hline 1. (Y. T.) & 75 & 87 \\
2. (U. S.) & 81 & 66 \\
3. (T, M.) & 80 & 82 \\
\hline
\end{tabular}

Table 6 Values of Laboratory Tests

\begin{tabular}{|c|c|c|c|c|c|c|c|c|c|c|c|c|c|c|}
\hline \multirow{2}{*}{\multicolumn{3}{|c|}{ Dose }} & \multirow{2}{*}{\multicolumn{2}{|c|}{$\begin{array}{l}\text { Case No. } \\
\text { (Subject) }\end{array}$}} & \multicolumn{2}{|c|}{$\begin{array}{l}\mathrm{WBC} \\
\left(/ \mathrm{mm}^{3}\right)\end{array}$} & \multicolumn{2}{|c|}{$\begin{array}{c}\mathrm{RBC} \\
\left(\times 10^{4} / \mathrm{mm}^{3}\right)\end{array}$} & \multicolumn{2}{|c|}{$\begin{array}{l}\text { Hemoglobin } \\
(\mathrm{g} / \mathrm{dl})\end{array}$} & \multicolumn{2}{|c|}{$\begin{array}{c}\text { Hematocrit } \\
(\%)\end{array}$} & \multicolumn{2}{|c|}{$\begin{array}{c}\text { Platelet } \\
\left(\times 10^{4} / \mathrm{mm}^{3}\right)\end{array}$} \\
\hline & & & & & before & after & before & after & before & after & before & after & before & before \\
\hline \multirow{3}{*}{\multicolumn{3}{|c|}{$\begin{array}{l}2 \mathrm{mg} \text {, i.v. } \\
\text { single }\end{array}$}} & \multirow{3}{*}{\multicolumn{2}{|c|}{$\begin{array}{l}\text { 1. }(\mathrm{Y} . \mathrm{T} .) \\
\text { 2. }(\mathrm{U} . \mathrm{S} .) \\
\text { 3. }(\mathrm{T} . \mathrm{M} .)\end{array}$}} & 8300 & 7800 & 487 & 473 & 14.9 & 14.6 & \multirow{2}{*}{$\begin{array}{l}43.4 \\
43.2\end{array}$} & 42.0 & \multirow{3}{*}{$\begin{array}{l}17.3 \\
24.6 \\
25.9\end{array}$} & \multirow{3}{*}{$\begin{array}{l}16.9 \\
31.9 \\
16.3\end{array}$} \\
\hline & & & & & 8200 & 7100 & 487 & 470 & 15.0 & 14.7 & & 41.0 & & \\
\hline & & & & & 7000 & 5900 & 499 & 487 & 16.2 & 15.9 & 45.8 & 44.9 & & \\
\hline \multirow{3}{*}{\multicolumn{3}{|c|}{$\begin{array}{l}5 \mathrm{mg} \text {, i.v. } \\
\text { single }\end{array}$}} & \multirow{3}{*}{\multicolumn{2}{|c|}{$\begin{array}{l}\text { 1. }(\mathrm{Y} . \mathrm{T} .) \\
\text { 2. }(\mathrm{U} . \mathrm{S} .) \\
\text { 3. }(\mathrm{T} . \mathrm{M} .)\end{array}$}} & 7100 & 8000 & 444 & 494 & 13.7 & 15.1 & \multirow{2}{*}{$\begin{array}{l}39.3 \\
40.5\end{array}$} & 43.7 & \multirow{3}{*}{$\begin{array}{l}21.5 \\
30.0 \\
34.1\end{array}$} & \multirow{3}{*}{$\begin{array}{l}16.4 \\
36.1 \\
26.3\end{array}$} \\
\hline & & & & & 7900 & 7100 & 462 & 451 & 14.1 & 14.0 & & 39.0 & & \\
\hline & & & & & 5800 & 6400 & 453 & 473 & 15.1 & 15.5 & 41.7 & 43.2 & & \\
\hline \multirow{3}{*}{\multicolumn{2}{|c|}{$\begin{array}{l}10 \mathrm{mg} \text {, i.v. } \\
\text { single }\end{array}$}} & & \multirow{3}{*}{\multicolumn{2}{|c|}{$\begin{array}{ll}\text { 1. } & (\mathrm{Y} . \mathrm{T} .) \\
\text { 2. } & (\mathrm{U} . \mathrm{S} .) \\
\text { 3. } & (\mathrm{T} . \mathrm{M} .)\end{array}$}} & 7000 & 7800 & 448 & 450 & 13.8 & \multirow{3}{*}{$\begin{array}{l}13.8 \\
14.4 \\
15.7\end{array}$} & \multirow{3}{*}{$\begin{array}{l}39.7 \\
42.2 \\
43.3\end{array}$} & 39.1 & \multirow{3}{*}{$\begin{array}{l}27.0 \\
36.3 \\
33.5\end{array}$} & \multirow{3}{*}{$\begin{array}{l}17.3 \\
27.3 \\
32.9\end{array}$} \\
\hline & & & & & 8100 & 8900 & 479 & 474 & 14.7 & & & 41.2 & & \\
\hline & & & & & 6100 & 7300 & 476 & 486 & 15.4 & & & 44.0 & & \\
\hline Proth & $\begin{array}{l}\text { rom } \\
(\mathrm{se}\end{array}$ & c) & time & $\begin{array}{r}\text { Total } \\
(\mathrm{g})\end{array}$ & $\begin{array}{l}\text { protein } \\
\text { (dl) }\end{array}$ & $\mathrm{A} / \mathrm{G}$ & -ratio & $\begin{array}{r}\text { Direct } \\
(m\end{array}$ & $\begin{array}{l}\text { t bilirub } \\
\text { ng/dl) }\end{array}$ & & $\begin{array}{l}\text { otal bili } \\
\text { (mg/d }\end{array}$ & $\begin{array}{l}\text { rubin } \\
\text { 1) }\end{array}$ & $\underset{(\mathrm{Karm}}{\mathrm{GC}}$ & T \\
\hline before & & & after & before & after & before & after & before & afte & & fore & after & before & after \\
\hline $28.8(34$ & & 30.8 & $8(32.1)$ & 7.2 & 7.4 & 1.6 & 1.7 & 0.11 & & .10 & 0.21 & 0.43 & 29 & 35 \\
\hline $26.8(34$ & & 31. & $9(32.1)$ & 6.6 & 6.6 & 1.5 & 1.6 & 0.03 & & .08 & 0.24 & 0.25 & 27 & 23 \\
\hline $28.1(34$ & & 28. & $9(32.1)$ & 7.0 & 7.1 & 1.4 & 1.7 & 0.08 & & .13 & 0.19 & 0.76 & 23 & 22 \\
\hline $26.9(32$ & & 31.1 & $1(32.5)$ & 6.8 & 7.0 & 1.5 & 1.5 & 0.13 & & .05 & 0.69 & 0.38 & 17 & 24 \\
\hline $26.9(32$ & & 29. & $0(32.5)$ & 6.2 & 6.6 & 1.6 & 1.5 & 0.13 & & .03 & 0.61 & 0.30 & 17 & 29 \\
\hline $28.6(32$ & & 33. & $0(32.5)$ & 6.4 & 7.1 & 1.4 & 1.7 & 0.13 & & .05 & 0.69 & 0.19 & 17 & 28 \\
\hline $25.8(33$ & & 29.8 & $8(30.8)$ & 7.1 & 6.8 & 1.5 & 1.5 & 0.16 & & .05 & 0.45 & 0.27 & 21 & 19 \\
\hline $27.8(33$ & & 31. & $2(30.8)$ & 6.8 & 6.6 & 1.7 & 1.5 & 0.19 & & .11 & 0.54 & 0.56 & 29 & 33 \\
\hline $27.6(33$ & & 28.8 & $8(30.8)$ & 7.0 & 7.0 & 1.7 & 1.6 & 0.16 & & .08 & 0.65 & 0.53 & 16 & 21 \\
\hline $\begin{array}{r}\mathrm{GP} \\
(\text { Karm } \\
\end{array}$ & & & LD & & $\underset{(\mathrm{L}}{\mathrm{Al}}$ & & $\begin{array}{r}\mathrm{Ch} \\
(\Delta \mathrm{pH}\end{array}$ & & $\mathrm{L}$ & & $\begin{array}{l}\mathrm{BL} \\
(\mathrm{mg}\end{array}$ & $\underset{/ \mathrm{dl})}{\mathrm{N}}$ & $\begin{array}{c}\text { Crea } \\
(\mathrm{m})\end{array}$ & $\begin{array}{l}\operatorname{tinine} \\
\mathrm{s} / \mathrm{dl})\end{array}$ \\
\hline before & aft & & before & after & before & after & before & after & before & after & before & after & before & after \\
\hline 23 & & 33 & 63 & 72 & 47 & 48 & 0.8 & 0.8 & 14 & 14 & 15 & 18 & 0.9 & 1.0 \\
\hline 16 & & 18 & 63 & 58 & 37 & 39 & 0.9 & 1.0 & 16 & 16 & 18 & 19 & 1.0 & 1.0 \\
\hline 15 & & 17 & 54 & 54 & 55 & 56 & 1.1 & 1.1 & 16 & 16 & 9 & 15 & 1.0 & 1.0 \\
\hline 16 & & 18 & 72 & 67 & 45 & 48 & 0.8 & 0.8 & 14 & 16 & 15 & 16 & 1.0 & 0.9 \\
\hline 13 & & 20 & 63 & 54 & 35 & 37 & 0.9 & 1.1 & 16 & 17 & 14 & 18 & 1.0 & 0.9 \\
\hline 11 & & 16 & 54 & 54 & 55 & 59 & 1.1 & 1.1 & 16 & 16 & 12 & 15 & 1.0 & 1.0 \\
\hline 15 & & 11 & 63 & 54 & 47 & 48 & 1.0 & 0.8 & 16 & 17 & 13 & 13 & 1.0 & 1.0 \\
\hline 21 & & 18 & 63 & 63 & 39 & 40 & 1.1 & 0.8 & 17 & 16 & 11 & 13 & 1.9 & 1.0 \\
\hline 15 & & 10 & 67 & 67 & 55 & 55 & 1.1 & 1.1 & 19 & 17 & 10 & 8 & 1.0 & 0.9 \\
\hline
\end{tabular}


Table 6 のつづき

\begin{tabular}{|c|c|c|c|c|c|c|c|c|c|c|c|c|c|c|}
\hline \multicolumn{2}{|c|}{$\begin{array}{l}\text { Total cholesterol } \\
(\mathrm{mg} / \mathrm{dl})\end{array}$} & \multicolumn{2}{|c|}{$\begin{array}{l}\text { Triglycerid } \\
(\mathrm{mg} / \mathrm{dl})\end{array}$} & \multicolumn{2}{|c|}{$\underset{(\mathrm{mEq} / \mathrm{l})}{\mathrm{Na}^{+}}$} & \multicolumn{2}{|c|}{$\underset{(\mathrm{mEq} / \mathrm{l})}{\mathrm{K}^{+}}$} & \multicolumn{2}{|c|}{$\left(\begin{array}{c}\mathrm{Cl}^{-} \\
\mathrm{mEq} / \mathrm{l})\end{array}\right.$} & \multicolumn{3}{|c|}{ MAO } & \multicolumn{2}{|c|}{$\begin{array}{c}\gamma-\mathrm{GTP} \\
(\mathrm{U})\end{array}$} \\
\hline before & after & before & after & before & after & before & after & before & after & before & aft & & before & after \\
\hline 168 & 169 & 158 & 117 & 139 & 144 & 4.6 & 4. & 107.3 & 105.4 & 24.1 & & .0 & 20 & 19 \\
\hline 148 & 163 & 74 & 106 & 148 & 143 & 4.9 & 4. & 104.8 & 106.2 & 28.3 & & .8 & 24 & 26 \\
\hline 160 & 165 & 98 & 72 & 146 & 147 & 4.6 & 4. & 104.5 & 104.9 & 31.4 & & .6 & 16 & 16 \\
\hline 161 & 149 & 87 & 78 & 143 & 140 & 4.3 & 3. & 105.9 & 105.1 & 26.0 & & .2 & 21 & 28 \\
\hline 152 & 155 & 69 & 67 & 145 & 142 & 4.5 & 4. & 105.3 & 106.2 & 28.6 & & .4 & 18 & 31 \\
\hline 137 & 127 & 73 & 67 & 144 & 144 & 4.8 & 3. & 103.3 & 104.5 & 29.5 & & .9 & 10 & 21 \\
\hline 139 & 140 & 75 & 65 & 144 & 143 & 4.4 & 4. & 102.3 & 105.3 & 26.5 & & .8 & 23 & 21 \\
\hline 157 & 156 & 76 & 57 & 141 & 140 & 4.0 & 4. & 102.5 & 102.7 & 34.2 & & 6 & 25 & 24 \\
\hline 141 & 143 & 71 & 64 & 144 & 141 & 4.0 & 4 & 101.7 & 101.4 & 37.7 & & 3 & 16 & 13 \\
\hline \multicolumn{2}{|c|}{$\begin{array}{l}\text { Glucose } \\
(\mathrm{mg} / \mathrm{dl})\end{array}$} & \multicolumn{2}{|c|}{$\begin{array}{c}\text { Urine } \\
\text { pH }\end{array}$} & \multicolumn{2}{|c|}{$\begin{array}{l}\text { Urine protein } \\
(\mathrm{mg} / \mathrm{dl})\end{array}$} & \multicolumn{3}{|c|}{$\begin{array}{l}\text { Urine sugar } \\
(\mathrm{mg} / \mathrm{dl})\end{array}$} & \multicolumn{3}{|c|}{ Urine urobilinogen } & \multicolumn{3}{|c|}{ Urine occult blood } \\
\hline before & after & before & after & before & after & & fore & after & before & afte & & & fore & after \\
\hline 89 & 75 & 6.0 & 6.5 & - & & - & - & - & \pm & & \pm & & - & - \\
\hline 98 & 96 & 6.0 & 6.0 & - & $+(57$ & & - & - & \pm & & \pm & & - & - \\
\hline 90 & 86 & 5.5 & 6.0 & - & & - & - & - & \pm & & \pm & & - & - \\
\hline 101 & 93 & 6.5 & 6.0 & - & & - & - & - & \pm & & \pm & & - & - \\
\hline 71 & 86 & 6.0 & 6.0 & - & & - & - & - & \pm & & \pm & & - & - \\
\hline 88 & 79 & 6.0 & 6.0 & - & & - & - & - & \pm & & \pm & & - & - \\
\hline 85 & 99 & 5.5 & 6.0 & - & & - & - & - & \pm & & \pm & & - & - \\
\hline 81 & 79 & 6.0 & 6.5 & - & & - & - & - & \pm & & \pm & & - & - \\
\hline 86 & 90 & 6.0 & 5.5 & - & & - & - & - & \pm & & \pm & & - & - \\
\hline
\end{tabular}

Table 7 Plasma Levels of Thymoxamine and its Metabolites in Subjects after Intravenous Single Administration of Thymoxamine

$10 \mathrm{mg}$, i. v., single

\begin{tabular}{|c|c|c|c|c|c|c|c|c|}
\hline \multirow{3}{*}{\multicolumn{2}{|c|}{$\begin{array}{l}\text { Case No. } \\
\text { (Subject) }\end{array}$}} & \multicolumn{6}{|c|}{ Plasma level $(\mu \mathrm{g} / \mathrm{ml})$} & \multirow{3}{*}{$\begin{array}{l}\mathrm{t} 1 / 2 \\
(\min )\end{array}$} \\
\hline & & \multicolumn{6}{|c|}{ Time after administration (min) } & \\
\hline & & 5 & 10 & 20 & 40 & 80 & 160 & \\
\hline 1. (T. M.) & DAM & 0.63 & 0.40 & 0.25 & 0.20 & 0.20 & 0.10 & \\
\hline & Met-X & 0.12 & 0.10 & 0.05 & 0.05 & 0.05 & 0.05 & \\
\hline \multicolumn{2}{|c|}{ DAM + Met $-\mathrm{X}$} & 0.75 & 0.50 & 0.30 & 0.25 & 0.25 & 0.15 & \\
\hline \multirow[t]{2}{*}{ 2. (Y.T.) } & DAM & 0.55 & 0.30 & 0.20 & 0.20 & 0.10 & 0.05 & \\
\hline & Met-X & 0.10 & 0.10 & 0.15 & 0.05 & 0.10 & 0.05 & \\
\hline \multicolumn{2}{|c|}{$\mathrm{DAM}+\mathrm{Met}-\mathrm{X}$} & 0.65 & 0.40 & 0.35 & 0.25 & 0.20 & 0.10 & \\
\hline \multirow[t]{3}{*}{ 3. (U.S.) } & DAM & 0.60 & 0.30 & 0.20 & 0.15 & 0.10 & 0.05 & \\
\hline & Met-X & 0.15 & 0.07 & 0.10 & 0.15 & 0.10 & 0.03 & \\
\hline & $\mathrm{DAM}+$ Met-X & 0.75 & 0.37 & 0.30 & 0.30 & 0.20 & 0.08 & \\
\hline \multirow[t]{3}{*}{$\begin{array}{l}\text { Mean } \\
\quad \pm \text { S. D. }\end{array}$} & DAM & $\begin{array}{l}0.59 \\
\pm 0.04\end{array}$ & $\begin{array}{l}0.33 \\
\pm 0.06\end{array}$ & $\begin{array}{l}0.22 \\
\pm 0.03\end{array}$ & $\begin{array}{l}0.18 \\
\pm 0.03\end{array}$ & $\begin{array}{l}0.13 \\
\pm 0.06\end{array}$ & $\begin{array}{l}0.07 \\
\pm 0.03\end{array}$ & \\
\hline & Met-X & $\begin{array}{l}0.12 \\
\pm 0.03\end{array}$ & $\begin{array}{l}0.09 \\
\pm 0.02\end{array}$ & $\begin{array}{l}0.10 \\
\pm 0.05\end{array}$ & $\begin{array}{l}0.08 \\
\pm 0.06\end{array}$ & $\begin{array}{l}0.08 \\
\pm 0.03\end{array}$ & $\begin{array}{l}0.04 \\
\pm 0.01\end{array}$ & \\
\hline & + Met $-X$ & $\begin{array}{l}0.72 \\
\pm 0.06\end{array}$ & $\begin{array}{l}0.42 \\
\pm 0.07\end{array}$ & $\begin{array}{l}0.32 \\
\pm 0.03\end{array}$ & $\begin{array}{l}0.27 \\
\pm 0.03\end{array}$ & $\begin{array}{l}0.22 \\
\pm 0.03\end{array}$ & $\begin{array}{l}0.11 \\
\pm 0.04\end{array}$ & 83 \\
\hline
\end{tabular}




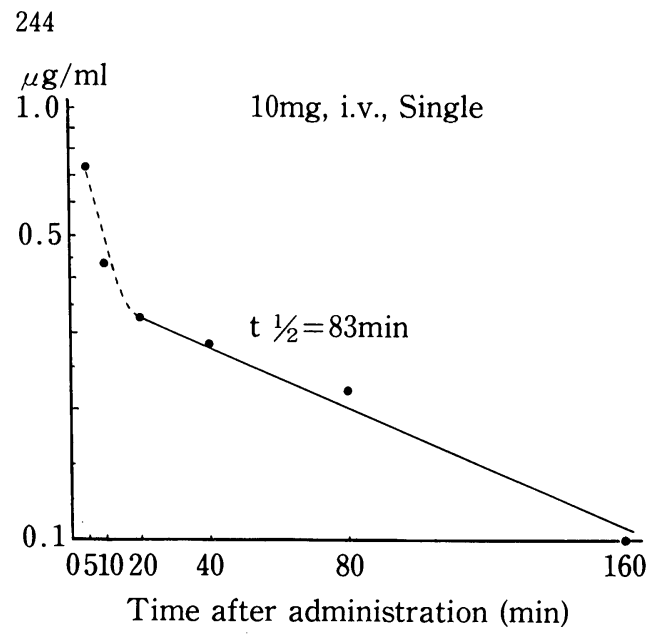

Fig. 7 Plasma level of thymoxamine and its metabolites after intravenous single administration of thymoxamine.

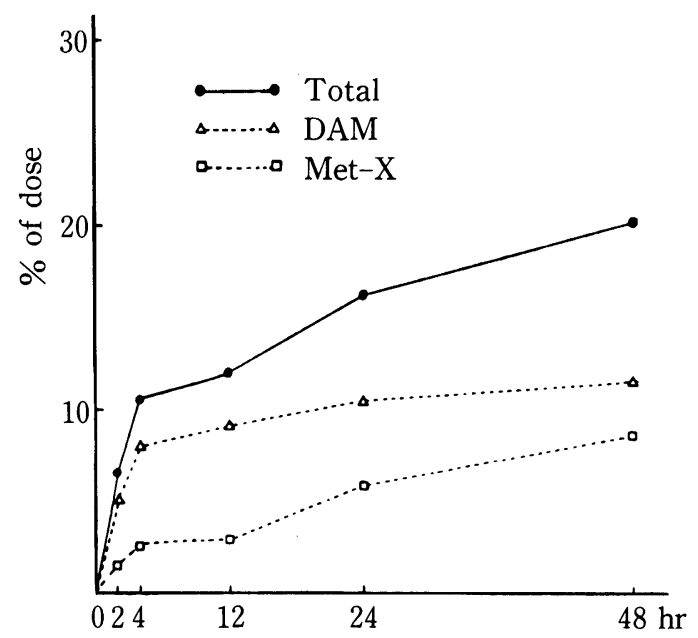

Fig. 8 Cumulative excretion ratio of thymoxamine and its metabolites in urine after intravenous administration of $10 \mathrm{mg}$ of thymoxamine.

Table 8 Comparison of Urinary and Fecal Excretion of Thymoxamine and its Metabolites in Subjects after Intravenous Administration of $10 \mathrm{mg}$ of Thymoxamine

\begin{tabular}{|c|c|c|c|c|c|c|}
\hline \multicolumn{3}{|c|}{$10 \mathrm{mg}$, i. v., single } & \multicolumn{4}{|c|}{ Urinary and fecal excretion (Dose \%) } \\
\hline \multirow{2}{*}{\multicolumn{3}{|c|}{$\begin{array}{l}\text { Case No. } \\
\text { (Subject) }\end{array}$}} & \multicolumn{3}{|c|}{ Time after administration (hr) } & \multirow{2}{*}{ Total } \\
\hline & & & $0-24$ & $24-48$ & $48-72$ & \\
\hline \multirow[t]{6}{*}{ 1. (U.S.) } & Urine & DAM & 11.2 & 0.9 & & 12.1 \\
\hline & & Met-X & 10.4 & 0.3 & & 10.7 \\
\hline & & $\mathrm{DAM}+$ Met $-\mathrm{X}$ & 21.6 & 1.2 & & 22.8 \\
\hline & Feces & DAM & 0.3 & 0.2 & 0.1 & 0.6 \\
\hline & & Met-X & 0.5 & 0.3 & 0.4 & 1.2 \\
\hline & & $\mathrm{DAM}+$ Met $-\mathrm{X}$ & 0.8 & 0.5 & 0.5 & 1.8 \\
\hline \multirow[t]{6}{*}{ 2. (Y.T.) } & Urine & DAM & 8.6 & 1.6 & & 10.2 \\
\hline & & Met-X & 3.2 & - & & 3.2 \\
\hline & & $\mathrm{DAM}+$ Met-X & 11.8 & 1.6 & & 13.4 \\
\hline & Feces & DAM & 0.3 & 0.2 & 0.3 & 0.8 \\
\hline & & Met-X & 0.6 & 0.5 & 0.3 & 1.4 \\
\hline & & $\mathrm{DAM}+$ Met $-\mathrm{X}$ & 0.9 & 0.7 & 0.6 & 2.2 \\
\hline \multirow[t]{6}{*}{ 3. (T. M.) } & Urine & DAM & 11.5 & 1.4 & & 12.9 \\
\hline & & Met-X & 4.1 & 7.9 & & 12.0 \\
\hline & & $\mathrm{DAM}+$ Met-X & 15.6 & 9.3 & & 24.9 \\
\hline & Feces & DAM & 0.3 & 0.3 & 0.2 & 0.8 \\
\hline & & Met-X & 0.6 & 0.4 & 0.3 & 1.3 \\
\hline & & DAM + Met-X & 0.9 & 0.7 & 0.5 & 2.1 \\
\hline \multirow[t]{6}{*}{ Mean } & Urine & DAM & 10.4 & 1.3 & & 11.7 \\
\hline & & Met-X & 5.9 & 2.7 & & 8.6 \\
\hline & & $\mathrm{DAM}+$ Met $-\mathrm{X}$ & 16.3 & 4.0 & & 20.3 \\
\hline & Feces & DAM & 0.3 & 0.2 & 0.2 & 0.7 \\
\hline & & Met-X & 0.6 & 0.4 & 0.3 & 1.3 \\
\hline & & DAM + Met-X & 0.9 & 0.6 & 0.5 & 2.0 \\
\hline
\end{tabular}


の変化をできるだけ詳細に観察するために，間歇 的でなく連続記録出来る機器を使用することとし た.しかし，被験者にほとんど侵襲を加えない方 法であることが望ましい，そこで上記のモニター を採用した。

その中で，自動連続収縮期血圧計は，耳介また は指尖で連続的に収縮期血圧を測定できる非観血 的測定器である7). 今回は指尖での測定を行った が，上腕血王よりやや低い值をとる．しかし相対 的変化をみる場合には問題はない，拡張期血圧は 測定できないため，従来のマンシェットによる上 腕血圧の測定も併用した，深部温度計は，室温に あまり影響されず，痛みや苦痛なく数時間の深部 温の測定が可能である.これは, 英国の R. H. Rox

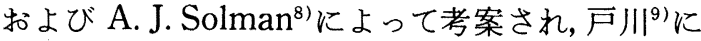
より改良されたものであるが，現在いろいろな臨 床応用が試みられている. 前額深部温は直腸温よ り $0.9 \pm 0.4^{\circ} \mathrm{C}$ 低いといわれるが，両者はよく相関 し, 前額深部温は直腸温の代用とされ得る. これ を中心温として，末梢四肢の深部温変化を経時的 に監視することにより，血行動態の監視が血圧の 変化に先行して可能になる，すなわち，血液は熱 の carrier であるので，深部温は測定部周辺の組 織の血流量をよく反映する10).

生理的食塩液の注射によっても，指尖皮膚温， 手掌・足蹠深部温は一過性に低下寸る. 注射後一 過性に認められた温度低下は，薬物によるもので なく, 注射行為による緊張, 痛みの影響と考えら れ，それに続く変化が薬の影響である。 Thymoxamine は，末梢血管を拡張させて血圧低下を起こ すことを示唆する．注射後訴えられた，手足の暖 まるよらな感じとか，軽度の顔面紅潮は，末梢血 管の拡張を裏づける.

$10 \mathrm{mg}$ 投与後発生した急性血圧低下例について は, 薬物の作用により末梢血管拡張状態にあると ころへ，採血がトリガーとなって血圧の急激な低 下が起きたと考えられる．上腕での血圧は 2 3 min で回復したが，深部温や手指での収縮期血圧 の回復がそれぞれ $15 \mathrm{~min}, 50 \mathrm{~min}$ と遅延を示し たのは, この血圧低下が決して一過性でないこと
を示唆している.これは上腕血圧だけでは得られ ない新たな情報を提供している。

一般に血圧は，収縮期圧より拡張期圧の低下が 著明であり，この点 $\mathrm{Arbab}^{11)} ら の$ 報告と一致す る.

血液学的検查, 尿検查, 血液生化学的検查とも, ほとんど正常範囲内の変動であり, 一定の傾向も なく，異常なしと判定した。

呼吸抵抗は 3 名とも上昇傾向であるが，動物実 験成績では，直接気管支筋を収縮する ${ }^{12)}$ ともいわ れるので，ヒトでも気導抵抗を上昇させるかもし れない，外国での臨床例では，気管支喘息発作に 用いて有効であること ${ }^{13)}$ や，運動後誘発される喘 息を抑えること视が報告されている，したがっ て，喘息患者と正常者では反応が異なるものと考 えられる。

血小板凝集抑制作用は，今回は全く認められな かった．抑制効果は in vitro では認められてい る ${ }^{12)}$ が，より高濃度であり臨床用量では認めにく いと考えられる。

臨床用量としては, 外国では 1 回 $10 \mathrm{mg}$ が用い られているが，今回の結果より日本人には $5 \mathrm{mg}$ の注射が安全と考えられる.

$$
\text { まとめ }
$$

1) Thymoxamine の静脈試験を 3 名の健常者 を対象に一週間隔で $2 \mathrm{mg}$ から $5,10 \mathrm{mg}$ と漸増し て行い, その安全性, 薬物動態, 薬力学的作用を 検討した。

2 ) 注射後 $24 \mathrm{hr}$ 以上入院監視下に挹き，ECG， 呼吸数, 収縮期血圧, 脈拍数, 深部温, 皮膚温, 皮膚血流を注射後 $1 \mathrm{hr}$ まで連続記録し, その変化 を観察するとともに安全性をチェックした．これ とは別に, 間歇的に上腕血圧, 脈拍数, 口腔内温 度を測定した。

3）血圧は低下傾向を示したが，特に拡張期血 圧の低下が著しかった。

4 ) 臨床検査值には, $24 \mathrm{hr}$ 後, 5 日後とも異常 は認められなかった。

5 ） $10 \mathrm{mg}$ 投与時, 3 名中 1 名は冷汗, 腹部蠕 
動を訴え急激な血圧低下を示した. 数 min で自然 に回復したが，深部温，手指血圧の回復はさらに 遅延した。

6 ）自覚症状として手足の暖まる感じ，頓部の 紅潮感があり，手足の深部温，皮膚温の増加より， これらは本剤の血管拡張作用のためと考光られ る.

7 ）血中濃度の半減期は $83 \mathrm{~min}$ であり，24 hr 尿中排泄率は $20.3 \%$ であり， $72 \mathrm{hr}$ 便中排泄率は $2.0 \%$ である.

8 ）持続収縮期血王計および深部温度計を循環 系モニターとして使用することにより，間歇的測 定では得られない情報が得られた。

\section{謝 辞}

終りに，本試験を行うにあたり，協力いただいた 県西部浜松医療センター循環器科西嶋憲治博士, 臨 床検査科岡本一也博士はじめ検査科の方々, 薬剤の 提供, 血中濃度, 尿中・便中排泄の測定を行われた 富士臓器製薬中央研究所の関係各位へ深謝の意を表 します。

\section{文 献}

1) 中島光好ほか: Thymoxamine hydrochloride の健常者による経口単一投与試験. 薬理と治療, 7 : 395-412 (1979).

2) 中島光好ほか: Thymoxamine hydrochloride の健常者による経口連続投与試験.薬理と治療, 7 : 585-603 (1979).

3) Myers, K. A. et al. : Haemodynamic action of thymoxamine in occlusive peripheral arte- rial disease. Cardiovascul. Res., $4: 360-366$ (1968).

4) Birmingham, A. T. et al. : Competitive blockade of adrenergic $\alpha$-receptors and histamine receptors by thymoxamine. J. Pharm. Pharmacol., 17 : 449-458 (1965).

5) Brownlee, G. : The use and abuse of vasodilator drugs. Angiology, 17 : 186-191 (1966).

6) Birmingham, A.T. et al.: A quantitative analysis of antagonism of intravenous noradrenaline by thymoxamine or phentolamine on the blood pressure of the conscious cat. J. Pharm. Pharmacol., 19 : 137-145 (1967).

7）万井正人ほか：島津テレメータ式最高血圧自動 連続測定装置 SCS-501。島津評論, $34: 81-86$ (1973).

8) Fox, R. H. et al. : A new method for monitoring the deep body temperature from the skin surface. Clinical Science, $44:$ 81-86 (1973).

9）戸川達男：深部体温計。（I）一基礎一. 電子 医学, $11: 41-53$ (1976).

10) Kobayashi, T. et al. : Analysis of the deep body thermometer for man. Ann. Biomed. Engng., 3 : 181-188 (1975).

11) Arbab, A. G. et al. : Effects of oral thymoxamine on blood pressure and pupillary response in normal subjects. J. Pharm. Pharmacol. 22 : 532-533 (1970).

12）平山八彦ほ力（富士蔵器製薬中央研究所）： Thymoxamine 薬理学的検索 (未発表).

13) Airaksinen, M. M. et al. : Alpha-adrenoceptor-blocking drugs in asthma. Brit. med. J., 1 : 394-395 (1975).

14) Bianco, J. P. et al. : Prevention of exercise"induced asthma by indramin. Brit. med. J., 4 : 18-20 (1974). 